\title{
Experimental Investigation on Strength Behaviour between GFRP \& Steel Bars Reinforced in Columns
}

\author{
M. Priyashagadevan ${ }^{1}$, K. A. Kalaiarasi ${ }^{2}$ \\ ${ }^{1}$ PG Student (M.E in Structural Engineering), Valliammai Engineering College, Chennai, India \\ ${ }^{2}$ Assistant Professor, Department of Civil Engg, Valliammai Engineering College, Chennai, India
}

\begin{abstract}
Glass Fibre Reinforced Polymer (GFRP) is a composite material, which consist of polyester thermosetting resin as matrix and glass fibres as reinforcement. Pultrusion technique is used to fabricate GFRP products in various continuousforms of structural sections such as box, I-, H-, and plates, which are similar as steel sections. The use of GFRP member in structures is relatively becoming more important especially in constructions. It was observed that the current required technical and design data of pultruded GFRP sections was rather limited especially with regard to material properties and structural performance. This study was conducted experimentally to investigate the physical and mechanical properties of the GFRP.
\end{abstract}

Keywords: Non-corrosivematerial, Compression strength, Split tensile strength

\section{Introduction}

Fiberglass refers to a group of products made from individual glass fibres combined into a variety of forms. Glass fibres can be divided into two major groups according to their geometry continuous fibres used in yarns and textiles, and the discontinuous (short) fibres used as batts, blankets, or boards for insulation and filtration. Fibreglass can be formed into yarn much like wool or cotton, and woven into fabric which is sometimes used for draperies. Fibreglass textiles are commonly used as a reinforcement material for molded and laminated plastics. Fibreglass wool, a thick, fluffy material made from discontinuous fibres, is used for thermal insulation and sound absorption. It is commonly found in ship and submarine bulkheads and hulls; automobile engine compartments and body panel liners; in furnaces and air conditioning units; acoustical wall and ceiling panels; and architectural partitions. Fibreglass can be tailored for specific applications such as Type E (electrical), used as electrical insulation tape, textiles and reinforcement; Type C (chemical), which has superior acid resistance, and Type $\mathrm{T}$, for thermal insulation. The basic raw materials for fibreglass products are a variety of natural minerals and manufactured chemicals. The major ingredients are silica sand, limestone, and soda ash. Other ingredients may include calcined alumina, borax, feldspar, nephelinesyenite, magnesite, and kaolin clay, among others. Silica sand is used as the glass former, and soda ash and limestone help primarily to lower the melting temperature. Other ingredients are used to improve certain properties, such as borax for chemical resistance. Waste glass, also called cullet, is also used as a raw material. The raw materials must be carefully weighed in exact quantities and thoroughly mixed together (called batching) before being melted into glass.

\section{Experimental Programme}

In this experimental program involves various processes of material testing, mix proportioning, mixing, casting and curing of test specimens. All the testing on materials was done in material testing laboratory, Valliammai engineering college Chennai.

\subsection{Materials Used}

The materials used in the preparation of concrete mix include cement, fine aggregates, coarse aggregates, GFRP rebar and steel bars. All the materials were tested and its physical properties are described below.

\subsubsection{Cement}

Ordinary Portland cement of 43 grade was used, conforming to recommendations stated in IS 403(1999). The normal consistency and initial setting time of cement was $30 \%$ and 30 minutes respectively.

\subsubsection{Fine Aggregate}

Coarse sand locally available is taken as fine aggregate. The test procedures as mentioned in IS-383(1970) were followed to determine the physical properties of fine aggregate as shown in Table 1.

\subsubsection{Coarse Aggregate}

The aggregates were tested in accordance to IS-383(1970). The results obtained are tabulated in Table 2.

\subsubsection{Glass Fibre Reinforced Polymer}

The basic raw materials for fibreglass products are a variety of natural minerals and manufactured chemicals. The major ingredients are silica sand, limestone, and soda ash. Other ingredients may include calcined alumina, borax, feldspar, nephelinesyenite, magnesite, and kaolin clay, among others. Silica sand is used as the glass former, and soda ash and limestone help primarily to lower the melting temperature. Other ingredients are used to improve certain properties, such as borax for chemical resistance. Waste glass, also called cullet, is also used as a raw material. The raw materials must be carefully weighed in exact quantities and thoroughly mixed together (called batching) before being melted into glass. 


\section{International Journal of Science and Research (IJSR) \\ ISSN (Online): 2319-7064}

Index Copernicus Value (2015): 78.96 | Impact Factor (2015): 6.391

\subsubsection{Water}

As per recommendation of IS: 456(2000), the water to be used for mixing and curing of concrete should be free from deleterious materials. Therefore, potable water was used in the present study in all operations demanding control over water quality.

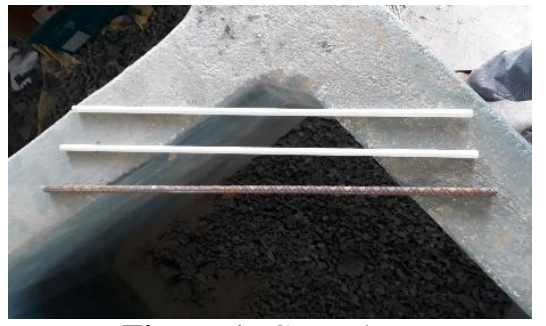

Figure 1: GFRP bars

Table 1: Physical properties of Fine aggregate

\begin{tabular}{|c|c|c|}
\hline Physical properties & Observed Values & Recommended Values \\
\hline Grading Zone & 2 & - \\
\hline Fineness Modulus & 2.70 & $2.9-3.2$ \\
\hline Specific Gravity & 2.54 & $2.3-2.67$ \\
\hline
\end{tabular}

Table 2: Physical properties of Coarse aggregate

\begin{tabular}{|c|c|c|}
\hline Physical properties & $\begin{array}{c}\text { Observed } \\
\text { Values }\end{array}$ & $\begin{array}{c}\text { Recommended } \\
\text { Values }\end{array}$ \\
\hline Fineness Modulus & 2.58 & $2.3-2.67$ \\
\hline Specific Gravity & 6.87 & $6.5-8.0$ \\
\hline Aggregate crushing value (\%) & 34.5 & Not more than $45 \%$ \\
\hline Aggregate impact value (\%) & 32.5 & Not more than $45 \%$ \\
\hline
\end{tabular}

Table 3: Physical properties of GFRP bar

\begin{tabular}{|c|c|}
\hline Physical properties & Recommended values from testing \\
\hline Diameter of bar & $12 \mathrm{~mm}$ \\
\hline Young's modules & 298970 \\
\hline Tensile strength $(\mathrm{N} / \mathrm{mm} 2)$ & $586.6 \mathrm{~N} / \mathrm{mm} 2$ \\
\hline
\end{tabular}

Table 4: Physical properties of steel bar

\begin{tabular}{|c|c|}
\hline Physical properties & Recommended values from testing \\
\hline Diameter of bar & $12 \mathrm{~mm}$ \\
\hline Young's modules & 200000 \\
\hline Tensile strength (N/mm2) & $486 \mathrm{~N} / \mathrm{mm} 2$ \\
\hline
\end{tabular}

\subsection{Methodology}

As per IS 10262: 2009 the mix proportion of concrete was done. To achieve specified characteristics at specific age, workability of fresh concrete and durability requirements proportioning is carried out. Grade M30 was proportioned according to the procedure as mentioned in the code.

\subsection{Mixing of Concrete, Casting and Curing of test Specimens}

The machine mixing was done during the entire process of casting. First the dry mix contains cement, coarse aggregate and fine aggregate was mixed for 2 minutes and with the addition of water again it will mix for 2 minutes until the mixture attains the homogeneous. Compaction was achieved by means of damping rod manually. All the specimens were demoulded after 24 hours and stored in curing tank until the age of testing.

\subsection{Test Methods}

The fresh concrete was tested for slump. Then the hardened concrete was tested for compressive strength and discussed below.

\subsubsection{Workability Test}

As per IS 1199-1959 slump test was done to find the workability. Slump cone test is the quick measure of workability of concrete mixes.

\subsubsection{Compressive Strength Test}

As per IS 516: 1959 compressive test was performed The test program consists of casting and testing three Columns in given size $150 \times 150 \times 900 \mathrm{~mm}$. The test specimen is mounted in a column testing frame of $500 \mathrm{kN}$ capacity. The Column are $900 \mathrm{~mm}$ in length and it is pinned supported.The load is applied at gradually which starts from the load 200 $\mathrm{KN}$.

\subsubsection{Tensile Test}

Tensile properties of bar and steel are tested and calculated by tensile machine.
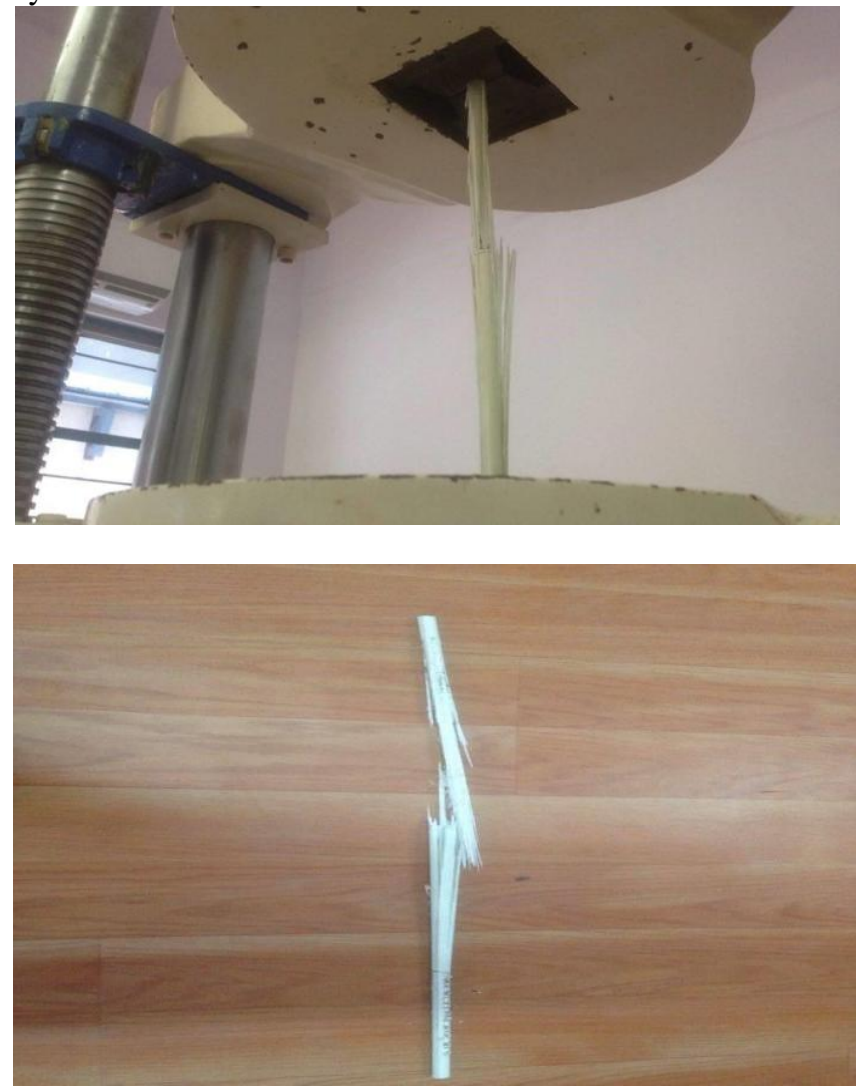

Figure 2: Tensile test on GFRP bar

Table 4: Tensile Strength on GFRP \& steel bar

\begin{tabular}{|c|c|c|c|c|c|}
\hline Type & $\begin{array}{c}\text { Diameter } \\
\text { of Bar }\end{array}$ & Area $\left(\mathrm{MM}^{2)}\right.$ & $\begin{array}{c}\text { Tensile } \\
\text { Strength } \\
\left(\mathrm{N} / \mathrm{mm}^{2}\right)\end{array}$ & $\begin{array}{c}\text { Peak } \\
\text { Load } \\
(\mathrm{KN})\end{array}$ & $\begin{array}{c}\text { Youngs } \\
\text { Modulus }\end{array}$ \\
\hline GFRP & $12 \mathrm{~mm}$ & 113 & 586.675 & 66.340 & 29897 \\
\hline STEEL & $12 \mathrm{~mm}$ & 113 & 486 & 55.41 & 200000 \\
\hline
\end{tabular}

\section{Results and Discussion}

The testing is carried out for 2 types of columns. Various comparisons were made in this test with these columns and

\section{Volume 6 Issue 7, July 2017 www.ijsr.net}




\section{International Journal of Science and Research (IJSR) \\ ISSN (Online): 2319-7064 \\ Index Copernicus Value (2015): 78.96 | Impact Factor (2015): 6.391}

the major parameters compared are strength, deflection, and various crack patterns of the columns.
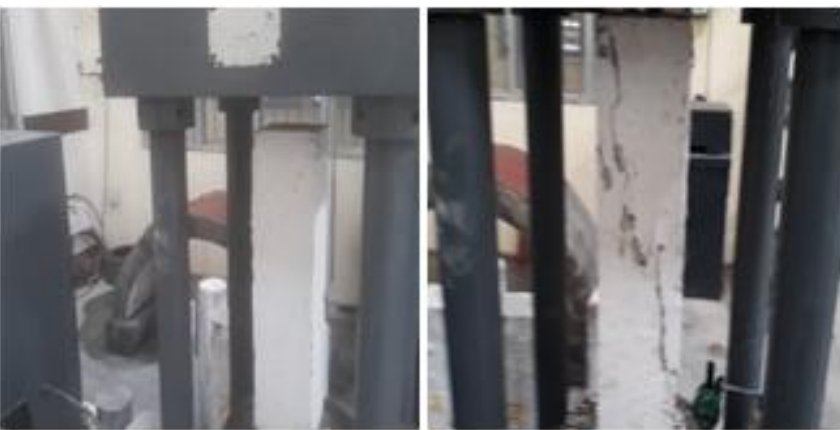

Figure 3: Compresion test on GFRP \& steel column

The columns are tested by using compression testing machine. The loads areapplied at gradually increasing upto the point of the cracks are obtained at initial stage. After that each load point is noted carefully until the ultimate load is occurred. The deflection of the columns are noted for the both GFRP and steel reinforced columns. By the test result we are able to know that GFRP column has more load carrying capacity than the steel reinforced column. Its nearly $10 \%$ to $20 \%$ of additional load carrying capcity of the GFRP column than the steel reinforced column.

So its proved that GFRP reinforced structurs.es are able carry more loads than the steel reinforced structures. The durability of the structure is also more occurs by the GFRP structure. We can see the comparison table and load deflection curve for the GFRP and steel reinforced column.

\subsection{Various Strength Criteria of Specimens}

Representative crack patterns at the conclusion of the test for the Column and specimens in the various test series are given. The cracking patterns for the specimens were quite similar when subjected to externally applied load. All specimens (control and strengthened) developed their first cracks within the constant region during initial loading. As the applied load increased, the cracks increased in number and started to develop as the load increased to failure, the cracks tended to fork out, and additional cracks formed.

Table 5: Ultimate load on columns

\begin{tabular}{|c|c|c|c|}
\hline S.no & Specimen Details & $\begin{array}{c}\text { Initial cracking } \\
\text { load }(\mathrm{kN})\end{array}$ & $\begin{array}{c}\text { Ultimate } \\
\text { load }(\mathrm{kN})\end{array}$ \\
\hline 1 & Reinforcement Column & 297 & 418.5 \\
\hline 2 & GFRP Column & 378 & 475.7 \\
\hline
\end{tabular}

The testing is carried out for 2 types of columns. Various comparisons were made in this test with these columns and the major parameters compared are strength, deflection, and various crack patterns of the columns.

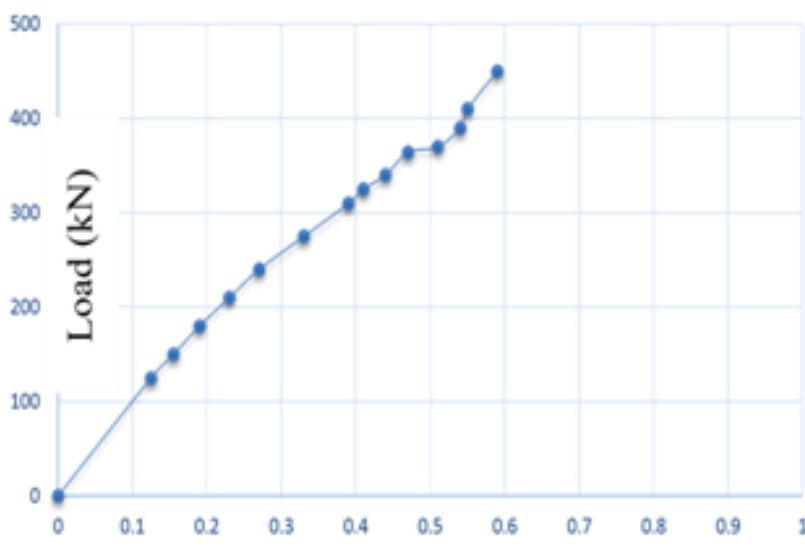

Displacement (MM)

Figure 4: Load deflection curve for GFRP reinforced column

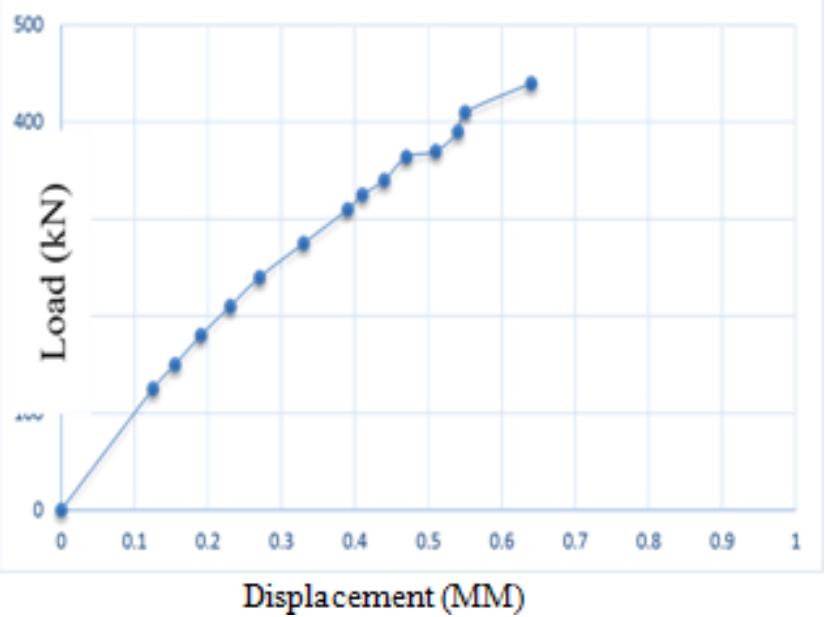

Figure 5: Load deflection curve for steel column reinforcement

In recent years, the using of GFRP has been successful for different concrete structure members. Although, the behavior of RC short columns has not been yet fully explored. The present study aims to provide basic technical information about the behavior of concrete column, reinforced longitudinally and transversally with GFRP bars and stirrups through experimental investigation and analytical study

\section{Conclusions}

Based on the experimental results carried out in this research considering the previous parameters associated with this research program, the following general conclusions can be drawn:

1) The GFRP and steel RC columns behaved in a similar manner and exhibited linear load-strain behavior in the ascending part up to $15 \%$ of their peak loads.

2) The axial capacities of the GFRP RC columns were on average $10 \%$ to $20 \%$ higher than their steel RC counterparts.

3) The tensile strength of GFRP bar is also more than steel bar. 


\section{International Journal of Science and Research (IJSR) \\ ISSN (Online): 2319-7064}

Index Copernicus Value (2015): 78.96 | Impact Factor (2015): 6.391

4) Since GFRP reinforcement is more effective at highly corrosion areas, it is more attractive and recommended to be used in field applications.

\section{Acknowledgement}

The inception and the rudimentary concepts of project are ascribable to my guide Ms.K.A.KALAIARASI,M.E., Assistant Professor, Department of Civil Engineering, without whose invaluable guidance, patient and encouragement, anything would have materialized. I owe my gratitude to him.

\section{References}

[1] Afifi, M. Z., Mohamed, H., and Benmokrane, B., [2013a]. - Axial Capacity of Circular Concrete Columns Reinforced with GFRP Bars and Spirals. \| Journal of Composites for Construction, In press.

[2] American Concrete Institute (ACI) Committee 440, [2006]. Guide for the Design and Construction of Concrete Reinforced with FRP Bars, ACI 440.1R-06, Farmington Hills, Mich.

[3] Issa, M. S., Metwally, I. M., and Elzeiny, S. M. [2011]. - Structural Performance of Eccentrically Loaded GFRP Reinforced Concrete Columns. \| International Journal of Civil and Structural Engineering, 2(1), 395-404.

[4] Lotfy, E. M. [2010]. - Behavior of Reinforced Concrete Short Columns with Fiber Reinforced Polymers Bars." International Journal of Civil and Structural Engineering, 1 (3), 545-557.

[5] Mirmiran, A. and Shahawy, M., [1997]. "Behavior of Concrete Columns Confined by Fiber Composites." Journal of Structural Engineering, 123 (5), 583-590.

[6] Zadeh, J. H., and Nanni, A. [2013]. -Design of RC Columns using Glass FRP Reinforcement.\|l Journal of Composite for Construction, 17(3), 294-304. 